\title{
Development of Phosphate-containing Polymer-based Solid Phase Extraction Procedure for the Separation, Enrichment, and Determination of Cadmium in Water and Food Samples by FAAS
}

\author{
Sumaira Khan ${ }^{\mathrm{a}, \mathrm{b}}$, Mustafa Soylak ${ }^{*}$, , Rasim Mirali Alosmanov ${ }^{\mathrm{c}}$, Tasneem Gul Kazi ${ }^{\mathrm{d}}$, \\ and Saghir Ahmed Sheikh ${ }^{b}$ \\ ${ }^{a}$ Erciyes University, Faculty of Sciences, Department of Chemistry, 38039 Kayseri, Turkey \\ ${ }^{b}$ Institute of Food Sciences and Technology, Faculty of Crop Production, Sindh Agriculture University, \\ Tandojam, Sindh 70060, Pakistan \\ c Baku State University, Chemistry Department, Baku, AZ1148, Azerbaijan \\ ${ }^{d}$ Center of Excellence in Analytical Chemistry, University of Sindh, Jamshoro 76080, Pakistan
}

\section{INTRODUCTION}

Cadmium (Cd) is the sixth most toxic pollutant and released into the environment by industry and through the food chain, thus contaminating air, soil, water and plants, and causing hazardous health effects to humans and animals even at very low levels (1-4) According to the U.S. Environmental Protection Agency (EPA), cadmium is also classified as a carcinogen at ultratrace level exposure (5-7). The determination of cadmium and other trace elements is difficult due to a very high concentration of matrix components in the environmental samples. Therefore, a very sensitive detection method with an enrichment-separation step is necessary prior to cadmium determination in environmental samples by flame atomic absorption spectrometry (FAAS).

Many separation/enrichment techniques for cadmium and other trace elements have been reported such as micelle extraction (8-10), solvent extraction $(11,12)$, coprecipitation with or without carrier element (13-14), ion-exchange (15) and solid phase extraction $(16,17)$.

Solid phase extraction is a welldeveloped and sophisticated approach for the separation/

*Corresponding autbor.

E-mail: msoylak@gmail.com

Tel: +90 352-2076666-33166

Fax: $+90352-4374933$

\begin{abstract}
A phosphorous-containing polymer (PhCP) has been used as an adsorbent for solid phase extraction (SPE) of cadmium at ultratrace levels. $\mathrm{Cd}^{2+}$ in aqueous solution was combined with 8-hydroquinoline and adsorbed on the PhCP column, then the desorption step was carried out with $3 \mathrm{~mL}$ of $3 \mathrm{M} \mathrm{HNO}_{3}$. Several analytical factors affecting the adsorption and enrichment efficiency of trace levels of cadmium include the $\mathrm{pH}$ of the solution, 8-hydroquinoline concentration, concentration of the eluent, and sample volume which were optimized to obtain good selectivity and quantitative extraction yield. The adsorption capacity of the PhCP sorbent was $9.0 \mathrm{mg} / \mathrm{g}$, the limit of detection (LOD) 0.41 $\mu \mathrm{g} / \mathrm{L}$ with a preconcentration factor of 20. The relative standard deviation of $25 \mu \mathrm{g} / \mathrm{L} \mathrm{Cd}$ was $4.23 \%$. The presented procedure was validated by the analysis of certified reference materials and the standard addition method. The analytical results showed good agreement with the certified values and the recoveries were in the range of $97-100 \%$. The method was successfully applied for the enrichment and determination of cadmium in water and food samples and analysis by FAAS.
\end{abstract}

enrichment of analytes at trace levels from different matrices. The main objective of solid phase extraction for traces of organic or inorganic species is the transfer of analyte elements from the aqueous phase to bind as suitable analytical form to active sites of the adjacent adsorbent (18). The most common adsorbents for solid phase extraction of traces of organic or inorganic species in environmental samples are Amberlite XAD resins (19), activated carbon (20), sodium dodecyl sulfate coated alumina (21), modified chromosorb resin (22), Dowex optipore resin (23), and sepiolite (24). Among these adsorbents, the phosphorus-containing polymer (PhCP) has become the most attractive due to its important sorptive properties such as a micro-porous structure, uniform pore distribution, high surface area, and an elevated extent of surface reactivity (25-27).

According to a literature survey, the phosphorus-containing polymer (PhCP) as an adsorbent has never been used for the separation and preconcentration of the Cd-oxine complex. In this study, the analytical parameters such as $\mathrm{pH}$, sample volume, eluent, etc., for the quantitative recovery of cadmium on the PhCP adsorbent were investigated.

\section{EXPERIMENTAL}

\section{Reagents and Standard Solutions}

Analytical reagent grade chemicals were used for all experimental work. Water purified through reverse osmosis was used for the 
preparation of solutions. A $0.1 \%$ (w/v) solution of oxine (Merck, Germany) in ethanol was prepared. A working solution of cadmium was prepared by dilution of 1000 $\mathrm{mg} / \mathrm{L}$ of stock solution (Fluka, Switzerland). $1 \mathrm{M} \mathrm{HNO}_{3}$ was used for serial dilution of the stock standard solution to make working standards. Butadiene Rubber (BR) was obtained from the Voronezh Synthetic Rubber Factory (Russia). Phosphorus trichloride and carbon tetrachloride (analytical reagent grade chemicals) were obtained from commercial sources $(25,28)$.

\section{Instrumentation}

A PerkinElmer ${ }^{\circledR}$ Model 3110 flame atomic absorption spectrometer (Shelton, CT, USA) was used. The hollow cathode lamp of cadmium was run according to the manufacturer's recommended conditions. Analysis was carried out with an air/acetylene flame using a 10-cm long slot burner head. Aliquots of $100 \mu \mathrm{L}$ of the aqueous samples were injected into the nebulizer of the FAAS using the microinjection method and peak height signals were recorded.

A Nel pH-900 pH meter ( Nel Company, Turkey) with a glass electrode was employed for $\mathrm{pH}$ measurements in the aqueous phase. Water was purified in a model RO 180 (Human Corporation, Korea), resulting in reverse osmosis water with a conductivity of $1 \mu \mathrm{S} / \mathrm{cm}$.

\section{Adsorbent}

The polymer under study is a synthesized industrial polymer, butadiene rubber (BR). The PhCP was prepared using a $2 \%$ solution of $\mathrm{BR}$ in $\mathrm{CCl}_{4}$, placed into a roundbottom flask in a temperature-controlled oxygenated environment. Then, $5 \mathrm{~mL}$ of $\mathrm{PCl}_{3}$ was added to the acidic reaction mixture which was vigorously agitated with oxygen. The escaping hydrogen chloride passes through the backflow condenser, is cooled by artificial ice, and caught by $2 \mathrm{M} \mathrm{NaOH}$. The amount of escaping hydrogen chloride was determined by titration of the stripping solution using a $\mathrm{HCl}$ test solution. After the reaction was finished, the phosphorylated BR (PhBR) was separated from the liquid. Then, the PhBR was treated with deionized water. Finally, the resulting solution was filtered, washed with distilled water up to achieving a neutral $\mathrm{pH}$, then washed with acetone and dried at room temperature. The mesh size of the PhCP adsorbent was in the $35-50$ range $(25,28)$.

\section{Adsorption Studies}

In the batch adsorption experiments, $0.2 \mathrm{~g}$ of PhCP was placed into a $100-\mathrm{mL}$ Erlenmeyer flask containing $50 \mathrm{~mL}$ of $150 \mu \mathrm{g} / \mathrm{mL}$ stock solution of $\mathrm{Cd}(\mathrm{II})$ at $\mathrm{pH}=7.0$. The flask was shaken at $150 \mathrm{rpm}$ in a mechanical shaker at room temperature for 24 hours. After decanting the aqueous phase, the Cd concentration at equilibrium (Ce) was determined. The capacity of PhCP was found to be $9.0 \mathrm{mg} / \mathrm{g}$, calculated according to the following equation:

$$
\mathrm{q}=\mathrm{V}(\mathrm{Co}-\mathrm{Ce}) / \mathrm{W}
$$

where Co and Ce are the initial and equilibrium concentrations of $\mathrm{Cd}$ $(\mu \mathrm{g} / \mathrm{mL})$, respectively. $\mathrm{V}$ is the volume of the solution ( $\mathrm{mL}$ ) and $\mathrm{W}$ is the mass of the adsorbent ( $\mathrm{g}$ ).

\section{Pre-treatment of Real Samples}

Camlik Lake water samples were taken (located in Yozgat, Turkey). Dam A, dam B, and wastewater samples (industrial effluent sites) were collected at Kayseri, Turkey. The water samples were collected into polyethylene plastic bottles (1.5 L capacity) which were previously soaked in $10 \%$ nitric acid for 24 hours and rinsed with ultrapure water before use. All water samples were filtered through a $0.45 \mu \mathrm{m}$ pore size cellulose nitrate membrane

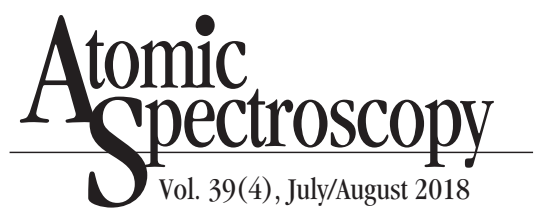

filter (Millipore Corporation, Bedford, MA, USA) and stored in a refrigerator at $4^{\circ} \mathrm{C}$ (29).

The procedure given in the "Test Procedure" section was applied to these water samples and the TMDA54.4 Fortified Lake Water certified water sample (National Water Research Institute of Canada Burlington, ON, Canada).

The different food samples (onion, tomato, green chili, and peppermint) were obtained at local markets in Kayseri. The food samples were dried in an electric oven at $80{ }^{\circ} \mathrm{C}$ for 48 hours and homogenized by grinding in an agate mortar, then sieved through a nylon sieve at $<125 \mu \mathrm{m}$ mesh size.

A wet acid digestion procedure was used for preparation of the food samples and the NIST CRM 1570 Spinach Leaves (National Institute of Science and Technology, Gaithersburg, MD, USA). Replicates of six samples of the CRM 1570 Spinach Leaves and duplicate food samples $(0.2 \mathrm{~g})$ were weighed directly into beakers and treated with $2 \mathrm{~mL}$ of a freshly prepared mixture of concentrated nitric acid-hydrogen peroxide (2:1, v/v). These were then left standing for 10 minutes at room temperature, heated on a hot plate until a semidried mass was obtained, dissolved in $5 \mathrm{~mL}$ of distilled water, and filtered through a filter paper (30). Finally, the proposed phosphoruscontaining polymer, based on the solid phase extraction (PhCP-SPE) procedure, was satisfactorily applied.

\section{Test Procedure}

For the SPE procedure, a glass column with an inner diameter of $1 \mathrm{~cm}$ and a length of $15 \mathrm{~cm}$ was loaded with $0.2 \mathrm{~g}$ of PhCP. A 2.0$\mathrm{mL}$ amount of appropriate buffer and $1 \mathrm{~mL}$ of $0.1 \%$ oxine (8-hydroxyquinoline) solution were added to a 10-100 mL sample solution (25 $\mu \mathrm{g} / \mathrm{L}$ of $\mathrm{Cd}$ ) in a glass beaker, and 
left standing for 10 minutes. The sample solution was passed through the column at $3 \mathrm{~mL} / \mathrm{min}$ under gravity. The elution step was carried out with $3 \mathrm{~mL}$ of $3 \mathrm{M}$ nitric acid and Cd was determined in the final solution by aspirating $100 \mu \mathrm{L}$ sample solution into the nebulizer of the FAAS. Blank solutions were submitted to the same procedure.

\section{RESULTS AND DISCUSSION}

\section{Effect of $\mathbf{p H}$}

The $\mathrm{pH}$ plays an important role in the quantitative solid phase extraction of Cd retained on PhCP. Therefore, the influence of $\mathrm{pH}$ on the PhCP-SPE procedure for $\mathrm{Cd}^{2+}$ was investigated at the $\mathrm{pH}$ range of 3.0-9.0. Figure 1 shows that maximum adsorption and extrac- tion recoveries of $\mathrm{Cd}$ were obtained at $\mathrm{pH} 7.0$ and was used in further experiments.

\section{Effect of Oxine Volume}

The effect of oxine (8-hydroxiquinoline) volume on the recovery values of cadmium was examined in the range of $200-1000 \mu \mathrm{L}$ by using $0.1 \%$ oxine solution (see Figure 2). The optimum ligand volume found for PhCP-SPE was $800 \mu \mathrm{L}$, while adding more ligand had no significant effect on the recovery of cadmium. Thus, $800 \mu \mathrm{L}$ was used for further experiments.

\section{Effect of Sample Volume}

The effect of sample volume on the recovery of cadmium was investigated. The $\mathrm{Cd}$ concentration was kept constant at $25 \mu \mathrm{g} / \mathrm{L}$, whereas

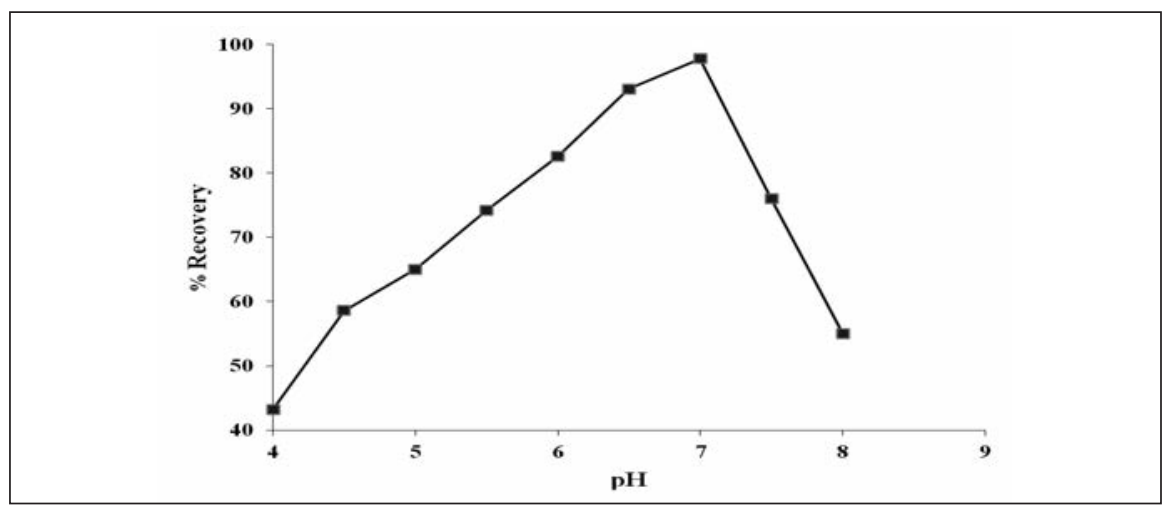

Fig. 1. Influence of $\mathrm{pH}$ on the recovery values of Cd ions $(0.1 \%$ oxine volume: $800 \mu \mathrm{L}$, eluent: $3 \mathrm{~mL}$ of $3 \mathrm{M}$ nitric acid, sample volume: $60 \mathrm{~mL}$ ).

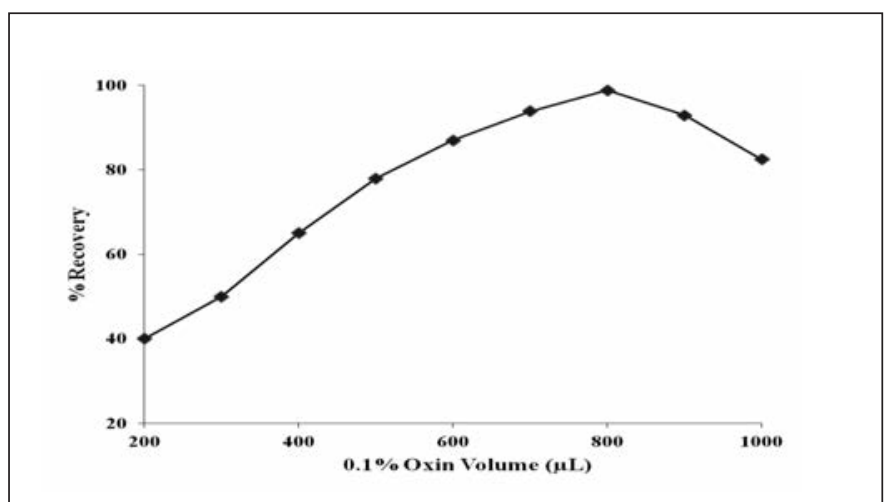

Fig. 2. Effect of oxine volume on the recovery of $\mathrm{Cd}(\mathrm{pH}$ : 7 , eluent: $3 \mathrm{~mL}$ of $3 \mathrm{M}$ nitric acid, sample volume: $60 \mathrm{~mL}$ ). the sample volume was increased from 10 to $100 \mathrm{~mL}$. When the sample volume was increased, a gradual decrease in the recovery was observed (see Figure 3). Quantitative recoveries were obtained up to $60 \mathrm{~mL}$. The preconcentration factor is calculated by the ratio of the highest sample volume $(60 \mathrm{~mL})$ and the lowest eluent volume $(3 \mathrm{~mL})$, and was calculated as 20 .

\section{Eluent}

Eluent type and its volume are two critical analytical parameters for the quantitative recovery of the analytes from the surface of the adsorbent in solid phase extraction studies. In order to achieve quantitative recoveries, a suitable solvent to analyte ions from the adsorbent must be investigated (31-34). In the present work, hydrochloric acid and nitric acid with concentrations of 1 and $3 \mathrm{M}$ were tested. The results in Figure 4 revealed that among all tested solvents, quantitative recovery was obtained with $3 \mathrm{M}$ nitric acid. The effect of different volumes $(3,5$, and $10 \mathrm{~mL})$ of $3 \mathrm{M}$ nitric acid on the recovery values was also evaluated. It was found that $3 \mathrm{~mL}$ of $3 \mathrm{M}$ nitric acid was suitable for quantitative elution.
Fig. 3. Influence of sample volume on the extraction efficiency
of cadmium ions ( $\mathrm{pH}: 7,0.1 \%$ oxine volume: $800 \mu \mathrm{L}$, eluent: $3 \mathrm{~mL}$ of $3 \mathrm{M}$ nitric acid). 

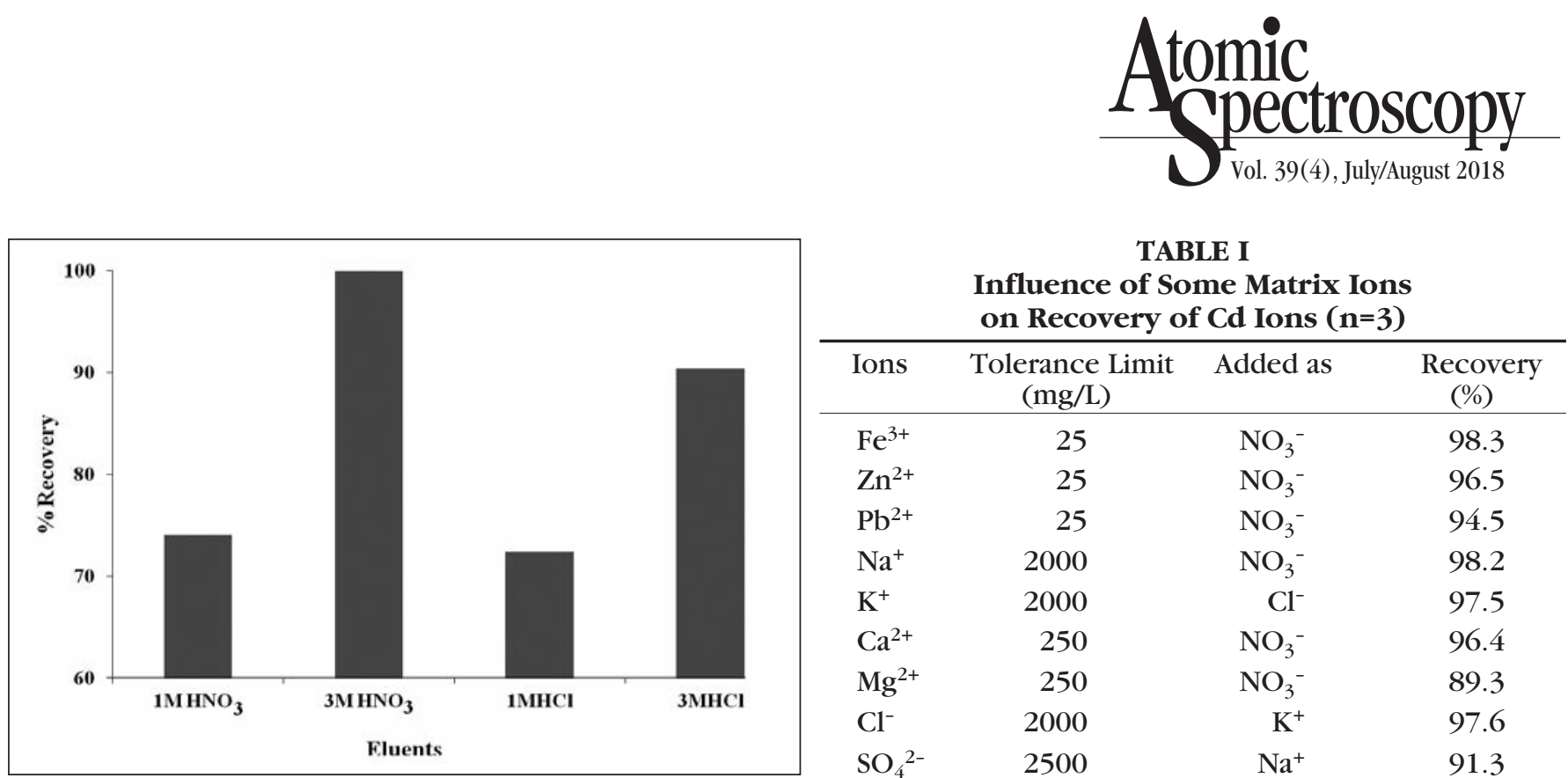

Fig. 4. Effect of eluent type and concentration on the extraction efficiency of analyte ions.

TABLE II

Addition/Recovery of $\mathrm{Cd}^{2+}$ in Water and Food Samples After PhCP-SPE Procedure

\begin{tabular}{lllc}
\hline Samples & Added & Found & $\begin{array}{c}\text { Recovery } \\
(\%)\end{array}$ \\
\hline Dam Water A & $0 \mu \mathrm{g} / \mathrm{L}$ & $17.3 \pm 0.001^{\mathrm{a}} \mu \mathrm{g} / \mathrm{L}$ & - \\
& $2 \mu \mathrm{g} / \mathrm{L}$ & $18.8 \pm 0.04 \mu \mathrm{g} / \mathrm{L}$ & $75^{\mathrm{b}}$ \\
& $5 \mu \mathrm{g} / \mathrm{L}$ & $22.0 \pm 0.10 \mu \mathrm{g} / \mathrm{L}$ & 94 \\
Onion & $0 \mu \mathrm{g} / \mathrm{g}$ & $6.19 \pm 0.02 \mu \mathrm{g} / \mathrm{g}$ & - \\
& $2 \mu \mathrm{g} / \mathrm{g}$ & $8.04 \pm 0.05 \mu \mathrm{g} / \mathrm{g}$ & 93 \\
& $5 \mu \mathrm{g} / \mathrm{g}$ & $11.3 \pm 1.26 \mu \mathrm{g} / \mathrm{g}$ & 102 \\
\hline
\end{tabular}

${ }^{a}$ Average of three determinations \pm standard deviation.

b \%Recovery $=$ Observed value of Cd $\overline{\text { Expected value of } \mathrm{Cd}} \times 100$

\section{Effect of Interfering Ions}

In the flame atomic absorption spectrometric determination of metals at trace levels in environmental samples, the matrix effects of the alkaline elements, earth alkaline elements, and anions are one of the most important and critical problems to investigate (35-38). To overcome these effects, a sample preparation step including enrichment and separation for real samples is necessity. For these reasons, the effects of interfering ions found in matrices of different real samples were studied. A 50-mL solution containing $25 \mu \mathrm{g} / \mathrm{L}$ of cadmium and interfering ions were subjected to the proposed SPE procedure. The results in Table I show that the separation and enrichment of Cd was quantitative, even when the interfering ions were at higher concentrations than would normally be found in real samples.

\section{Analytical Figures of Merit}

Under the optimum experimental conditions, 99.9\% extraction recovery was achieved. The calibration graph for cadmium was linear in the range of $10-200 \mu \mathrm{g} / \mathrm{L}$ and is described by the following equation, $[y=(0.2438)(\mathrm{Cd})+(0.0053)]$ with a correlation coefficient of 0.9982 , where $y$ is the absorbance and concentration of $\mathrm{Cd}$. The limit of detection was calculated at 0.41
TABLE I

Influence of Some Matrix Ions on Recovery of Cd Ions $(n=3)$

\begin{tabular}{ccc}
$\begin{array}{c}\text { Tolerance Limit } \\
(\mathrm{mg} / \mathrm{L})\end{array}$ & Added as & $\begin{array}{c}\text { Recovery } \\
(\%)\end{array}$ \\
\hline 25 & $\mathrm{NO}_{3}{ }^{-}$ & 98.3 \\
25 & $\mathrm{NO}_{3}{ }^{-}$ & 96.5 \\
25 & $\mathrm{NO}_{3}{ }^{-}$ & 94.5 \\
2000 & $\mathrm{NO}_{3}{ }^{-}$ & 98.2 \\
2000 & $\mathrm{Cl}^{-}$ & 97.5 \\
250 & $\mathrm{NO}_{3}{ }^{-}$ & 96.4 \\
250 & $\mathrm{NO}_{3}{ }^{-}$ & 89.3 \\
2000 & $\mathrm{~K}^{+}$ & 97.6 \\
2500 & $\mathrm{Na}^{+}$ & 91.3
\end{tabular}

$\mu \mathrm{g} / \mathrm{L}$ as three times the standard deviation of the blank signals. The relative standard deviation for a minimum of six replicates was $4.23 \%$.

\section{Applications}

In order to evaluate the accuracy of the PhCP-SPE procedure, addition/recovery studies were performed and the results are summarized in Table II. Moreover, the applicability of the proposed methodology was evaluated by the analysis of CRM TMDA-54.4 Fortified Lake Water and NIST 1570a Spinach Leaves. The concordant results of $\mathrm{Cd}$ with the certified values are listed in Table III.

The optimized PhCP-SPE procedure was applied for the preconcentration, separation and determination of cadmium in water and acid-digested vegetables (onion, tomato, green chili and peppermint) samples. The results are given in Table. IV.

The comparative data of different analytical characteristics of some previously reported separation and preconcentration procedures are listed in Table $\mathrm{V}$. These show that the obtained LOD, EF, and operating time of the proposed methodology are generally much better than the reported separation/ 
TABLE III

Determination of Cd in CRMs as an Application of the Proposed PhCP-SPE Method

\begin{tabular}{lccc}
\hline Certified Reference Materials & $\begin{array}{c}\text { Certified } \\
\text { Value }\end{array}$ & $\begin{array}{c}\text { Experimental } \\
\text { Value }\end{array}$ & $\begin{array}{c}\text { Recovery } \\
(\%)\end{array}$ \\
\hline TMDA-54.4 Fortified Lake Water & $158 \mu \mathrm{g} / \mathrm{L}$ & $155 \pm 2.0^{\mathrm{a}} \mu \mathrm{g} / \mathrm{L}$ & 98.1 \\
NIST SRM 1570a Spinach Leaves & $2.89 \mu \mathrm{g} / \mathrm{g}$ & $2.88 \pm 0.27 \mu \mathrm{g} / \mathrm{g}$ & 99.8 \\
\hline
\end{tabular}

${ }^{a}$ Average \pm standard deviation $(n=6)$.

TABLE V

Comparison of PhCP-SPE Procedure With Preconcentration Techniques for Cd

\begin{tabular}{|c|c|c|c|c|c|}
\hline Methods & $\mathrm{PF}$ & $\begin{array}{c}\text { LOD } \\
(\mu \mathrm{g} / \mathrm{L})\end{array}$ & $\begin{array}{l}\text { Linear Range } \\
(\mu \mathrm{g} / \mathrm{L})\end{array}$ & Adsorbent & Ref. \\
\hline FI-on line & 26 & 0.23 & - & DDTC & $(40)$ \\
\hline SPE & - & 1.44 & $216-3000$ & nano $\mathrm{B}_{2} \mathrm{O}_{3} / \mathrm{TiO}_{2}$ & (41) \\
\hline SPE & - & 5.50 & $5-150$ & Moringa oliefera seeds & $(42)$ \\
\hline VALLME & 35 & 2.9 & $10-250$ & $\begin{array}{l}\text { 1-Octyl-3-methyl } \\
\text { imidazolium Hexafluoro- } \\
\text { phosphate }\end{array}$ & $(43)$ \\
\hline USAEME & - & 0.19 & $1-1000$ & Carbon tetrachloride & $(44)$ \\
\hline PhC-SPE & 20 & 0.41 & $10-200$ & $\begin{array}{l}\text { Phosphorous-containing } \\
\text { polymer }\end{array}$ & $\begin{array}{l}\text { This } \\
\text { work }\end{array}$ \\
\hline
\end{tabular}

PF: preconcentration factor, LOD: limit of detection, FI-on line: flow injection online coprecipitation; SPE: Solid phase extraction; USAEME: ultrasound assisted emulsification microextraction; VALLME: vortex assisted liquid -liquid microextraction.

enrichment methods for cadmium (39-52). Thus, it can be stated that the proposed preconcentration procedure can satisfactorily be applied for the analysis of different environmental and biological samples without experiencing any systematic error.

\section{CONCLUSION}

PhCP-SPE combined with FAAS was evaluated for the separation and preconcentration of $\mathrm{Cd}$ at trace level in environmental and different vegetable samples. Cadmium ions as oxine complexes were quantitatively recovered at $\mathrm{pH} 7.0$ and desorbed by using $3 \mathrm{~mL}$ of $3 \mathrm{M}$ $\mathrm{HNO}_{3}$. The adsorption capacity of the PhCP sorbent was $9.0 \mathrm{mg} / \mathrm{g}$, the limit of detection (LOD) $0.41 \mu \mathrm{g} / \mathrm{L}$ with a preconcentration factor of 20 . The adsorbent could be used at
TABLE IV

Level of Cd in Some Samples After Application of PhCP-SPE Procedure $(n=3)$

\begin{tabular}{lc}
\hline Samples & Concentration \\
\hline Dam water A & $17.3 \pm 0.001^{\mathrm{a}} \mu \mathrm{g} / \mathrm{L}$ \\
Dam water B & $42.8 \pm 0.01 \mu \mathrm{g} / \mathrm{L}$ \\
Lake water & $58.4 \pm 1.2 \mu \mathrm{g} / \mathrm{L}$ \\
River water & $143.2 \pm 2.3 \mu \mathrm{g} / \mathrm{L}$ \\
Onion & $6.19 \pm 0.02 \mu \mathrm{g} / \mathrm{g}$ \\
Tomato & $6.85 \pm 0.03 \mu \mathrm{g} / \mathrm{g}$ \\
Green chili & $1.93 \pm 0.01 \mu \mathrm{g} / \mathrm{g}$ \\
Peppermint & $4.98 \pm 0.05 \mu \mathrm{g} / \mathrm{g}$
\end{tabular}

Notes: Permissible levels of $\mathrm{Cd}$ in water and food as per WHO and FAO are $0.3 \mu \mathrm{g} / \mathrm{g}$.

${ }^{\mathrm{a}}$ Mean \pm standard deviation

\section{REFERENCES}

1. M. Varol, and M.R. Sunbul, Environ. Pollut. 230, 311 (2017).

2. L. Abramsson-Zetterberg, A.C. Vikstrom, M. Tornqvist, and K.E. Hellenas, Toxicol. Environ. Mutagen. 653, 50 (2008).

3. A. Duran, M. Tuzen, and M. Soylak, Environ. Monit. Assess., 186, 4619 (2014).

4. D. Mohan and K.P. Singh, Water. Res. 36, 2304 (2002).

5. A. Duran, M. Tuzen, and M. Soylak, Atom. Spectrosc. 34, 99 (2013).

6. S. Mol, F.S. Karakulak, and S. Ulusoy, Turk. J. Fish. Aquat. Sc., 17, 1135 (2017).

7. L. Jarup and L. Akesson, Toxicol. Appl. Phamacol. 238, 201 (2009).

8. P.R. Aranda, R.A. Gil, S. Moyano, I.D. Vito, and L.D. Martinez, Talanta 77, 663 (2008).

9. A. Shokrollahi, M. Ghaedi, O. Hossaini, N. Khanjari, and M. Soylak, J. Hazard. Mater. 160, 435 (2008). 
10. E.Z., Jahromi, A. Bidari, Y. Assadi, M.R.M. Hosseini, and M.R. Jamali, Anal. Chim. Acta 585, 305 (2007),.

11. A.N. Anthemidis, G.A. Zachariadis, C.G. Farastelis, and J.A. Stratis, Talanta 62, 437 (2004).

12. N. Pourreza, and K.J. Ghanemi, J. Hazard. Mater. 178, 566 (2010).

13. S. Saracoglu, M. Soylak, and L. Elci, Talanta 59, 287 (2003).

14. M. Soylak, and N.D. Erdogan, J. Hazard. Mater. 137, 1035- (2006).

15. C. L. Ye, Q. X. Zhou, and X.M. Wang, Anal. Chim. Acta 572, 165 (2006).

16. A.N. Anthemidis, G. Giakisikli, S. Xidia, and M. Miro, Microchem. J. 98, 66 (2011).

17. M. Tuzen, and M. Soylak, J. Hazard. Mater. 164, 1428 (2009).

18. Z.A. ALOthman, M. Habila, E. Yilmaz, and M. Soylak, Microchim. Acta 177, 397 (2012).

19. S.L.C., Ferreira, C.F. Brito, A.F. Dantas, N.M.L. Araujo, and A.C.S. Costa, Talanta 48, 1173 (1999).

20. S. Cerutti, S. Moyano, J.A. Gasquez, J. Stripeikis, R.A. Olsina, and L.D. Martinez, Spectrochim. Acta. 58B, 2015-2021 (2003).

21. M. Ghaedi, M.E. Asadpour, and A. Vafaie, Bull. Chem. Soc. Jpn. 79, 432-436 (2006).

22. M. Ghaedi, M.R. Fathi, A. Shokrollahi, and F. Shajarat, Anal. Lett. 39, 1171 (2006).

23. M. Soylak, L. Elci, and M. Dogan, J. Trace Microprobe T. 19, 329 (2001).

24. Soylak, M., S. Saracoglu, L. Elci, and M. Dogan, Kuwait J. Sci. Eng. 30, 95 (2003).

25. R.M. Alosmanov, A.A. Azizov, and A.M. Magerramov, Russian J.
Gen. Chem. 81, 1477 (2011).

26. R. M. Alosmanov, M. Szuwarzyński, J. Schnelle-Kreis, G. Matuschek, A. M. Magerramov, A. A. Azizov, R. Zimmermann, and S. Zapotoczny, Nanotechnology 29, 135708 (2018).

27. R.M. Alosmanov, K. Wolski, G. Matuschek, A. Magerramov, A. Azizov, R. Zimmermann, E. Aliyev, and S. Zapotoczny Therm. Anal. Calorim. 130, 799 (2017)

28. A.A. Azizov, A.M. Maharramov, R.M. Alosmanov, K.N. Orujeva, and I.A. Bunyadzadeh, Inter. Polym. Sci. Tech. 41, 6 (2013).

29. S. Khan, E. Yilmaz, T.G. Kazi, and M. Soylak, Clean- Soil, Air, Water 42, 1083 (2014),

30. S. Khan, T.G. Kazi, and M. Soylak, Spectrochim. Acta 123A, 194 (2014).

31. M. Soylak, U. Divrikli, and M. Dogan, J. Trace Microprobe T. 15, 197 (1997).

32. C. Kutahyali, and M. Eral, J. Sep. Pur. Technol. 40, 109 (2004).

33. S.M. Yolcu, M. Firat, D.S. Chormey, Ç. Büyükpınar, F. Turak, and S. Bakirdere, B. Environ. Contam. Tox. 100, 715 (2018).

34. M. Soylak, L. Elci, and M. Dogan, Anal. Lett. 30, 623 (1997).

35. M. Soylak, and Z. Erbas, Atom. Spectrosc. 38, 57 (2017).

36. J.D. Ivassechen, A.D.O. Jorgetto, M.H.P. Wondracek, A.C.P. Da Silva, L.F. Zara, V.D. Pedrosa, B.P. Rocha, M.J. Saeki, and G.R. Castro, Turk. J. Chem. 42, 547 (2018).

37. M. Ghaedi, F. Ahmadi, and M. Soylak, Ann. Chim-Rome 97, 277 (2007).

38. Z. Ozbas, S. Demir, and $\mathrm{H}$. Kasgoz, J. Polym. Environ. 26, 2096
(2018).

39. M. Rezaee, Y. Assadi, M. Hosseini, E. Aghaee, F. Ahmadi, and S. Berijani, J. Chromatogr. 1116A, 1 (2006).

40. H. Chen, J. Jin, and Y. Wang, Anal. Chim. Acta 353,181 (1997).

41. O. M. Kalfa, O. Yalcinkaya, and A.R. Turker, J. Hazard. Mater. 166, 455 (2009).

42. V.N. Alves, R. Mosquetta, N.M.M. Coelho, J.N. Bianchin, K.C.D.P. Roux, E. Martendal, and E. Carasek, Talanta 80, 1133 (2011).

43. M. Chamsaz, A. Atarodi, M. Eftekhari, S. Asadpour, and M. Adibi, J. Adv. Res. 4, 35 (2013).

44. H. Sereshti, Y.E. Heravi, and S. Samadi, Talanta 97, 235 (2012).

45. M. Ghaedi, F. Ahmadi, Z. Tavakoli, M. Montazerozohori, A. Khanmohammadi, and M. Soylak, J. Hazard. Mater. 152, 1248 (2008).

46. M. Soylak, L. Elci, and M. Dogan, J. Trace Microprobe T. 17, 149 (1999).

47. M. Soylak, and Y. Akkaya, L. Elci, Int. J. Environ. An. Ch. 82, 197 (2002).

48. S. Sivrikaya, and M. Imamoglu Anal. Lett. 51, 773 (2018).

49. C.E. Dogan, Fresen. Environ. Bull. 27, 1989 (2018).

50. F. Iranzad, M. Gheibi, and M. Eftekhari, Int. J. Environ. An. Ch. 98, 16 (2018).

51. H. Yadaei, M.H. Beyki, F. Shemirani, and S. Nouroozi, React. Funct. Polym. 122, 85 (2018).

52. M. Soylak, L. Elci, and M. Dogan, Anal. Lett. 26, 1997(1993). 